\title{
'N EVALUASIE VAN GEDRAGSTERAPIE BY DIE BEHANDELING VAN FUNKSIONEEL DISFONIE BY KINDERS
}

\author{
W. G. NEL \\ Hoofterapeut by die Transvaalse Onderwysdepartement, Pretoria
}

In hierdie studie is daar gepoog om 'n evaluasie te doen van die gebruik van ' $n$ gedragsterapeutiese benadering by die behandeling van funksionele disfonie by kinders; 'n nuwe benaderingswyse van die probleem is voorgestel ten einde meer permanente resultate te verseker. Neurotiese gedrag word deur die gedragsterapeute as aangeleerde gedrag beskou en derhalwe interesseer enige terapie wat gebaseer is op die beginsels van die leerproses, hulle veral. ${ }^{7}$ Die term ,gedragsterapie' is vir die eerste keer deur prof. H. J. Eysenck gebruik in 1958 tydens een van sy lesings.

Die leerbeginsels is alreeds so vroeg as 1927 deur Pavlov bestudeer en veral die begrip klassieke kondisionering is deur hom omskryf.

Tipes Kondisionering. Vandag is daar twee belangrike tipes kondisionering naamlik:

(a) Klassieke kondisionering (kortliks, wanneer 'n respons van die proefpersoon onvermydelik is).

(b) Opcrant kondisionering (wanneer die eksperimenteerder wag totdat die respons op natuurlike wyse ontstaan).

Laasgenoemde proses het sy ontstaan van die eksperimentele bevindings van Bechterev en Thorndike. Hulle belangrikste opvolger was B. F. Skinner wat dan ook die term, operant kondisionering' vir die eerste keer in $193^{8}$ gebruik het. Kenmerkend van hierdie prosedure, is dat die gedrag van die proefpersoon op sigself instrumenteel is vir die aanbieding of weglating van versterking (beloning) of straf.

Daar is verskeie operante kondisioneringsprosedures wat gebruik kan word, byvoorbeeld gedrag wat 'n angename verloop vir die individu tot gevolg het sal meer geredelik voorkom as gedrag wat 'n onaangename gevolg vir die individu intiou. Indien die terapeut 'n spesifieke responspatroon van die individu wil versterk, behoort opleiding d.m.v. beloning (d.i. wanneer die produksie van 'n spesifieke respons lei tot 'n doelwit waartoe die individu gemotiveer is) die doeltreffendste te wees. Opleiding d.m.v. beloning is veral effektief wanneer die gedrag wat dié terapeut wil versterk, glad nie aanwesig is nie en daar dus weinig is om te beloon. In sulke gevalle begin die terapeut om gedrag wat min of meer lyk op die gewenste gedrag te beloon. Wanneer sodanige gedragspatroon voldoende versterk is, kan hoër verwagtinge daargestel word voordat 'n respons beloon word, sodat slegs die gewenste gedrag uiteindelik beloon word. 'n Soortgelyke aaneenlopende prosedure word genoem ,shaping' of ,successive approximation'.

Uit die werk van verskeie navorsers word dit duidelik dat strafopleiding 
'n uiters ontoereikende prosedure is om 'n gedragspatroon deurgaans uit te skakel. 'n Meer effektiewe prosedure vir die uitskakeling van 'n sekere gedragspatroon blyk die volgende te wees: nl. om die weglating van ongewenste gedrag aan te moedig deur 'n tydelike uitsluiting van beloning in plaas van spesifieke straf. Lg. prosedure is veral van waarde wanneer die mate waarin die ongewenste gedrag voorkom, minder opvallend is. Die ongewenste gedrag lei dan tot 'n vermindering van enige positiewe versterking. Die pasiënt kan ook beloon word in 'n situasie vir die weglating van tot nog toe ongewenste gedrag (weglatingsopleiding), veral wanneer sodanige ongewenste gedrag dikwels voorkom. Verskeie skedules vir versterking kan gebruik word. Wanneer 'n terapeut 'n sekere gedragspatroon, telkens wanneer dit na vore kom, versterk, toon dit spoedig 'n toename in frekwensie en die terapie bereik sy doelwit. Operant kondisionering bied groot geleenthede vir individuele verskille en kan sodoende aangepas word by die pasiënt sowel as by die terapeut (wat verskillende prosedures kan gebruik).

Wat die tipe van beloning aanbetref wat die terapeut wil gebruik, is daar verskeie moontlikhede. Dit is nodig dat die terapeut die kardinale belang van gekontroleerde versterking aan die pasiënt besef en derhalwe die verskillende faktore, wat 'n rol mag speel by beloning, vóór die aanvang van 'n terapieprogram bepaal. Die ondersoek na enige sodanige faktore moet so noukeurig moontlik beplan word, omdat daar nie slegs vasgestel moet word of die gekontroleerde beloning in sy doel slaag nie, maar ook of daar nie enige ander faktore ongemerk tydens terapie in werking was en verkeerdelik versterk is nie, bv. 'n glimlag van die terapeut kan net soveel beloningswaarde hê as ' $n$ ander vorm van beloning. Wanneer die terapeut sou glimlag wanneer sy dit nie spesifiek as 'n beloning op 'n sekere'moment wil gebruik nie, sou die operante kondisioneringsprosedure nie konsekwent deurgevoer word nie. Hieruit blyk dit duidelik dat die rol van die terapeut tydens 'n operante kondisioneringsprosedure nie maklik is nie. Dit is verder noodsaaklik dat die terapiesessies noukeurig geadministreer word: dit is van die uiterste belang by die evaluasie van die terapie en kan dien as 'n waardevolle hulpmiddel vir die terapeut om haar eie doelstellings te hersien en om haar eie gedrag, waar moontlik, reg te stel.

Operante Kondisioneringsterapie. Wanneer operante kondisioneringsterapie begin word, is dit veral van belang dat die onmiddellike omgewing van die pasiënt deeglik op hoogte is van die terapieprogram en 'n goeie insig daarin het. Die nodige instruksies moet dus vooraf gegee word aan die ouers, onderwysers, verpleegsters ens. of wie ook al tydens die terapie met die kind gemoeid is, sodat die pasiënt nie buite die terapiesessies met heeltemal ' $n$ verskillende beloningsisteem gekonfronteer word nie.

By die behandeling van die disfoniese kind moet die ouers veral saamwerk; van die uiterste belang is om toe te sien dat die ouers nie die gebruik van die verkeerde stemgewoonte versterk deur aandag daaraan te gee juis wanneer dit voorkom nie. Straf het skynbaar geen motiverende waarde vir die kind om die goeie stemtoon te gebruik nie (soos wat 
negatiewe oefening het vir die vaslegging van 'n sekere klank in spontane spraak nie): dit plaas alleen groter druk op die kind. Die ouer kan die terapiesessies bywoon ten einde te leer om die goeie stemkwaliteit onmiddellik te herken (sodat dit tuis ook beloon kan word). Die moeder kan van die uiterste hulp wees om situasies waar die stem tuis minder goed was, aan die terapeut te rapporteer.

Volgens Rachman ${ }^{6}$ kan die toepassing van die operante kondisioneringstegnieke, sowel as meer bekende metodes van gedragsterapie, verder van onskatbare waarde wees, veral in die gebied van die kindersielkunde.

Die algemene oorsaak van kinderdisfonieë, is stembandknobbeltjies, wat te wyte kan wees aan oorsake soos 'n verkeerde spreekstemtoonhoogte, ooreising van die stem deur oormatige geskreeu of 'n té harde insit van die aanvangsklanke ens. ${ }^{5}$ Volgens Greene is die heropleiding van kinderstemme moeilik, ondat permanente resultate a.g.v. hulle ouderdomme, nie maklik verkry word deur stemoefeninge, of deur hulle ts belet om hulle stemme te ooreis nie. Spraakterapie behoort dus eers op elfjarige leeftyd in aanvang te neem indien die disfonie dan nog bestaan. Sy is van mening dat die herstel van die toestand op hierdie ouderdom ook spontaan kan geskied. In alle gevalle van stemmisbruik het die toestand van die pasiënt se vokale patroon heelwat te doen met sy aangebore konstitusie, sy algemene gesondheid, sy vatbaarheid vir verkoues en sy reaksie op spanning. Babas wat hees word na baie huil, mag later in hulle lewens as volwassenes disfonieë ontwikkel. ${ }^{4}$

Damsté noem ook die probleem van hoe 'n permanente verandering in 'n foutiewe stemgewoonte verkry kan word." Heelwat van die kinders met stemprobleme wat onlangs by die Afdeling Spraakpatologie van die Universiteitskliniek te Utrecht ondersoek is, toon duidelike tekens van gespannenheid en kom senuweeagtig van geaardheid voor. Indien hierdie senuweeagtigheid uitgeskakel kon word (afgeleer kon word volgens die gedragsterapeute deur die proses van wederkerige remming van angs) sou die verkryging van meer permanente resultate makliker wees.

Die belangrikste aanduiding vir die noodsaaklikheid van verdere navorsing in die moontlike toepassing van tegnieke soos hierbo beskryf in die gebied van kinderdisfonieë, is 'n verslag deur Gray, England en Mahoney' oor die suksesvolle behandeling van 'n volwassene met stembandknobbeltjies, deur middel van gedragsterapie volgens die metode van wederkerige remming soos beskryf deur Wolpe.

Die tegniek van ,sistematiese ongevoeligmaak' wat gebruik' word by die proses van wederkerige remming, blyk uiters bruikbaar te wees vir die stemterapeut ten einde meer permanente resultate te verkry by die behandeling van funksionele disfonieë. Dit kan veral van hulp wees by die cordrag van die nuwe stem na situasies wat nog vir die pasiënt angs mag inhou. Volgens Wolpe is dit nie noodsaaklik om die gevreesde voorwerp of situasie werklik aan te bied nie, aangesien daar slegs van 'n angshiërargie gebruik gemaak kan word. Sodoende, kan hierdie metode van werk veral tydbesparend wees.

fournal of the South African Logopedic Society, Vol. I5, No. I: December 1968 


\section{Opsomming van Bevindings}

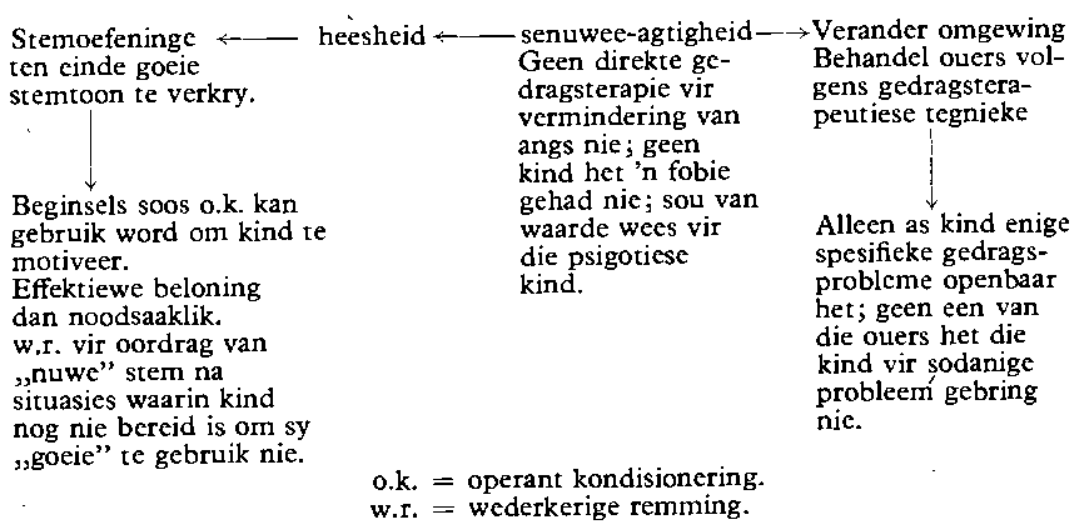

Operante kondisioneringsprosedures-met die gebruik van effektiewe versterking-kan dus van nut wees ten einde meer permanente resultate te verkry en om die kind sover te kry om die goeie stem so gou moontlik te gebruik (stemoefeninge kan van nut wees om 'n beter stemtoon o.l.v. die stemterapeut te verkry; die kind moet leer om die goeie en die minder goeie stemtoon te onderskei).

Daar kon slegs ' $n$ begin gemaak word met die behandeling van kinders en derhalwe is dié deel van die ondersoek as 'n voorstudie beskou. Alhoewel hierdie werkmetode veel van die terapeut verg en oënskynlik tydrowend is, is dit 'n intensiewer werkswyse, gegrond op 'n meer wetenskaplike beskouing van die verskillende beloningsisteme as sodanig. Afgesien van die waarde van effektiewe beloning waarop dit wys, dui dit ook op die noodsaaklikheid van verdere gekontroleerde eksperimentele toepassing van gedragsterapie op die gebied van funksionele stemstoornisse.

Hierdie studie is gedoen onder leiding van dr. P. H. Damsté, hoof van die afdeling Foniatrie, aan die Universiteitskliniek te Utrecht.

\section{Opsomming}

Terapie gebaseer op beginsels van die leerteorie word bespreek, en die behavioristiese benadering tot terapie vir kinders met knobbels op die stemplooie word ge-evalueer.

\section{Summary}

Therapy based on learning principles is discussed, and a behaviourist approach to the difficulties of therapy for children with nodular laryngitis is evaluated. 


\section{BIBLIOGRAFIE}

I. Bakker, B. (1967): Operante konditionering-Ongepubliseerde lesing in kinderpsigiatrie gehou te Utrecht op 9 November 1967 by die ,Stichting Academisch Ziekenhuis Utrecht.'

2. Damsté, P. H. (1967): Stembandknobbeltiies. Logopedic en foniatrie, 39, 95-98, J. B. Wolters, Groningen.

3. Gray, B. B., England, G., and Mahoney, J. L. (1965): Treatment of Vocal Nodules by Reciprocal Inhibition. Journal of Behaviour Research and Therapy, 3, I87-193, London.

4. Greene, M. C. L. (1957): The Voice and its Disorders. Pitman Mcdical Publishing Co., Ltd.

5. Mednick, S. A. (I964): Psychologie van het Leren. Prentice Hall, Inc., Englewood Cliffs, N.J.

6. Rachman, S. (I962): Child Psychology and Learning Theory. Journal of Child Psychology and Psychiatry, 2, I49-I63.

7. Santer-Weststrate, H. C. (1964): Gedragsterapie. Van Gorcum and Co.

8. Wilson, D. K. (I96I): Children with Vocal Nodules. Journal of Speech and Hearing Disorders, 26, 19-26.

9. Wolpe, J. (1958): Psychotherapy by Reciprocal Inhibition. Stanford University Press, Stanford, California, and Witwatersrand University Press, Johannesburg. 